\title{
Clostridium peptidivorans sp. nov., a peptide-fermenting bacterium from an olive mill wastewater treatment digester
}

\author{
Tahar Mechichi, ${ }^{1}$ Marie-Laure Fardeau, ${ }^{1}$ Marc Labat, ${ }^{1}$ Jean-Louis Garcia, ${ }^{1}$ \\ Fréderic Verhé ${ }^{1}$ and Bharat K. C. Patel ${ }^{2}$
}

1 Laboratoire IRD de Microbiologie, Université de Provence, CESB/ESIL, Case 925, 163 Avenue de Luminy, 13288 Marseille cedex 9, France

2 School of Biomolecular and Biomedical Sciences, Faculty of Science, Griffith University, Brisbane, Queensland 4111, Australia

Author for correspondence: Bharat Patel. Tel: +61 417 726671. Fax: +61 738757800. e-mail: bharat@genomes.sci.gu.edu.au

\begin{abstract}
A new peptide-degrading, strictly anaerobic bacterium, designated strain TMC4 ${ }^{\top}$, was isolated from an olive mill wastewater treatment digester. Cells of strain TMC4 ${ }^{\top}$ were motile, rod-shaped (5-10 $\times$ 0.6-1.2 $\left.\mu \mathrm{m}\right)$, stained Gram-positive and formed terminal to subterminal spores that distended the cells. Optimal growth occurred at $37{ }^{\circ} \mathrm{C}$ and $\mathrm{pH} 7$ in an anaerobic basal medium containing $0.5 \%$ Casamino acids. Arginine, lysine, cysteine, methionine, histidine, serine, isoleucine, yeast extract, peptone, Biotrypcase, gelatin and crotonate also supported growth, but not carbohydrates, organic acids or alcohols. The endproducts of degradation were: acetate and butyrate from lysine and crotonate; acetate, butyrate, $\mathrm{H}_{2}$ and $\mathrm{CO}_{2}$ from Biotrypcase, gelatin and peptone; acetate, alanine, $\mathrm{H}_{2}$ and $\mathrm{CO}_{2}$ from cysteine; acetate, $\mathrm{H}_{2}$ and $\mathrm{CO}_{2}$ from serine, cysteine and yeast extract; acetate and formate from histidine; propionate from methionine; methyl 2-butyrate, $\mathrm{H}_{2}$ and $\mathrm{CO}_{2}$ from isoleucine; acetate and ethanol from arginine; and acetate, propionate, butyrate, methyl 2-butyrate, $\mathrm{H}_{2}$ and $\mathrm{CO}_{2}$ from Casamino acids. The DNA G+C content of strain TMC4 ${ }^{\top}$ was 31 mol\%. Phylogeny based on 16S rRNA sequence analysis showed that strain TMC4 ${ }^{\top}$ was a member of the low-G+C-content Gram-positive genus Clostridium, with the closest relative being Clostridium pascui (sequence similarity of $96 \%$ ). Due to considerable differences in genomic and phenotypic properties between strain $\mathrm{TMC4}^{\top}$ and those of its nearest relative, strain $\mathrm{TMC4}^{\top}$ is proposed as a new species of the genus Clostridium, Clostridium peptidivorans sp. nov. Strain TMC4 $^{\top}$ has been deposited in the DSMZ as strain DSM $12505^{\top}$.
\end{abstract}

Keywords: Clostridium peptidivorans, peptides, amino acids, olive mill wastewater, digester

\section{INTRODUCTION}

Olive mill wastewater is a dark liquid that contains high concentrations of biopolymers such as proteins, polysaccharides and polyphenols and is a cause of severe pollution in the Mediterranean basin. Agroindustrial wastewater has been shown to be treated successfully in anaerobic methanogenic digesters (Lettinga, 1995). Hamdi (1996) has proposed the use of similar systems to treat olive mill wastewater. In

The GenBank accession number for the 165 rDNA sequence of strain TMC4 is AF156796. order to understand the anaerobic digestion processes occurring in olive oil waste treatment, we have recently isolated and characterized several new species of anaerobic microbes that degrade aromatic compounds (Mechichi et al., 1999). In this paper, we report the isolation and characterization of a new peptidefermenting bacterium, Clostridium peptidivorans sp. nov.

\section{METHODS}

Sample source. Strain TMC4 ${ }^{\mathrm{T}}$ was enriched from samples collected from an anaerobic methanogenic digester (Sfax, Tunisia) fed with olive mill wastewater. The samples were 
collected anaerobically using a $\mathrm{N}_{2}$-flushed syringe and transferred directly to a sterile anaerobic serum bottle, which was maintained at room temperature until use. The digester temperature was set at $37^{\circ} \mathrm{C}$ with no $\mathrm{pH}$ control.

Culture medium. The basal medium used for enrichment, isolation and cultivation contained $\left(1^{-1}\right.$ distilled water $): 1 \mathrm{~g}$ yeast extract, $1 \mathrm{~g} \mathrm{NH}_{4} \mathrm{Cl}, 0.3 \mathrm{~g} \mathrm{~K}_{2} \mathrm{HPO}_{4}, 0.3 \mathrm{~g} \mathrm{KH}_{2} \mathrm{PO}_{4}, 0.6 \mathrm{~g}$ $\mathrm{NaCl}, 0 \cdot 1 \mathrm{~g} \mathrm{CaCl}{ }_{2} \cdot 2 \mathrm{H}_{2} \mathrm{O}, 0 \cdot 2 \mathrm{~g} \mathrm{MgCl}_{2} \cdot 6 \mathrm{H}_{2} \mathrm{O}, 0 \cdot 1 \mathrm{~g} \mathrm{KCl}$, $1.5 \mathrm{ml}$ trace element solution (Widdel \& Pfennig, 1981) and $1 \mathrm{mg}$ resazurin. The $\mathrm{pH}$ was adjusted to 7 with $10 \mathrm{M} \mathrm{KOH}$ solution and the medium was made anaerobic using techniques described previously (Hungate, 1969; Macy et al., 1972; Miller \& Wolin, 1974).

Enrichment, isolation and cultivation. Enrichment, isolation and cultivation were performed in $5 \mathrm{ml}$ basal medium containing $0.5 \%$ Casamino acids followed by incubation at $37{ }^{\circ} \mathrm{C}$, as described previously (Mechichi et al., 1999). Pure cultures were obtained by picking single well-isolated colonies from dilution series by using the roll-tube method (Hungate, 1969). Studies of optimum growth conditions and electron acceptor utilization were performed with $0.5 \%$ Casamino acids as the substrate.

Substrate utilization. Substrate utilization studies were performed in basal medium containing complex substrates at $0.5 \%$ (Biotrypcase, yeast extract, gelatin and peptone), carbohydrates at $20 \mathrm{mM}$ (glucose, fructose, xylose, ribose, sorbose, sorbitol, sucrose, melibiose, raffinose, galactose, myo-inositol, lactose, cellobiose, mannitol, mannose, arabinose, arabitol, cellulose and xylan), organic acids at $20 \mathrm{mM}$ (formate, acetate, propionate, butyrate, valerate, crotonate, fumarate, malonate, malate, lactate, citrate and succinate) or amino acids at $10 \mathrm{mM}$ (arginine, alanine, proline, histidine, serine, aspartate, glycine, threonine, glutamate, glutamine, leucine, isoleucine, aspartate, asparagine, valine, methionine, lysine, tyrosine, phenylalanine and tryptophan), as described by Mechichi et al. (1999).

Cellular studies. Gram staining was performed using a kit purchased from Sigma. Light microscopy and electron microscopy were performed as described by Fardeau et al. (1997).

Analytical methods. Growth was determined by measuring changes in optical density at $580 \mathrm{~nm}$ by inserting anaerobic Hungate tubes directly into the cuvette holder of a Shimadzu model UV 160A spectrophotometer. Acetate, propionate, butyrate, formate, isobutyrate, ethanol and methyl 2butyrate were measured by HPLC (Spectra Series 100 model; Thermo Separation Products) equipped with an Aminex HPX-87X $300 \times 7 \cdot 8$ (inside diameter) mm column (Bio-Rad) connected to a differential refractometer (RID6A; Shimadzu). Analysis was performed using a CR-6A Shimadzu integrator. The mobile phase was $0.0025 \mathrm{M}$ $\mathrm{H}_{2} \mathrm{SO}_{4}$ at a flow rate of $0.6 \mathrm{ml} \mathrm{min} \mathrm{mi}^{-1}$ and the column temperature was $35^{\circ} \mathrm{C}$. The volume of the injection loop was $20 \mu \mathrm{l}$. Amino acid concentrations were determined by HPLC according to Moore et al. (1958). Sulfide was measured photometrically as colloidal $\mathrm{CuS}$ by using the method of Cord-Ruwisch (1985).

$\mathrm{H}_{2}$ and $\mathrm{CO}_{2}$ were measured using a gas chromatograph GC$8 \mathrm{~A}$ (Shimadzu) equipped with a thermal conductivity detector, a C-R6A integrator (Shimadzu) and a Chromosorb WAW 80/100 mesh sp100 column (Alltech). $\mathrm{N}_{2}$ at a pressure of $100 \mathrm{kPa}$ was used as the carrier gas. The detector and the injector temperature was $200^{\circ} \mathrm{C}$, the column temperature was $150^{\circ} \mathrm{C}$.
Determination of $\mathbf{G}+\mathbf{C}$ content. The $\mathrm{G}+\mathrm{C}$ content of DNA was determined at the DSMZ by HPLC (Mesbah et al., 1989). Non-methylated lambda DNA (Sigma) was used as the standard.

DNA extraction, amplification and sequencing of the $16 \mathrm{~S}$ rDNA gene. DNA extraction, 16S rDNA amplification and sequencing were performed as described previously (Redburn \& Patel, 1993; Andrews \& Patel, 1996; Mechichi et al., 1999). The universal primers Fdl and Rd1 were used to obtain a PCR product of approximately $1.5 \mathrm{~kb}$ corresponding to base positions 28-1539 of the numbering of Escherichia coli 16S rDNA (Winker \& Woese, 1991). The new sequence data that were generated, consisting of 1481 nucleotides, were aligned and an almost full-length consensus 16S rRNA gene sequence was assembled and checked for accuracy manually using the ae 2 alignment editor (Maidak et al., 1999). These were compared with other sequences in the GenBank database (Benson et al., 1993) by using BLAST (Altschul et al., 1997) and in the Ribosomal Database Project, version 7.0, by using SIMILARITY-RANK and SUGGEST-TREE (Maidak et al., 1999). Reference sequences most closely related to our newly generated sequences were extracted from these databases and aligned. Positions of sequence and alignment uncertainty were omitted from the analysis. Pairwise evolutionary distances based on 1128 unambiguous nucleotides were computed by using DNADIST (Jukes and Cantor option) and neighbourjoining programs that form part of the PHYLIP suite of programs (Felsenstein, 1993). TREECON was used extensively for bootstrap analysis (Van de Peer \& De Wachter, 1993).

\section{RESULTS}

\section{Morphology}

Several pure cultures were obtained and one of the cultures was designated strain $\mathrm{TMC}^{\mathrm{T}}$ and studied further. As strain TMC4 ${ }^{\mathrm{T}}$ did not grow on glucose, basal medium containing glucose was routinely used to check culture purity. Cells of strain $\mathrm{TMC} 4^{\mathrm{T}}$ were rodshaped $(0 \cdot 6-1 \cdot 2 \times 5-10 \mu \mathrm{m})$. Spores were oval and were located terminally or subterminally, and they distended the cells (Fig. 1a). The cells stained Grampositive and possessed a thick Gram-positive-type cell wall ultrastructure (Fig. 1b). Cells were motile and possessed peritrichous flagella.

\section{Physiology}

Strain $\mathrm{TMC}^{\mathrm{T}}$ was a strictly anaerobic and chemoorganotrophic bacterium. Growth occurred between 20 and $42{ }^{\circ} \mathrm{C}$ with the optimum temperature for growth at $37^{\circ} \mathrm{C}$. The optimum $\mathrm{pH}$ for growth was 7 and no growth occurred below pH $6 \cdot 0$ or above $\mathrm{pH} 9 \cdot 0 . \mathrm{NaCl}$ was not required for growth, but was tolerated up to $4 \%$.

\section{Substrate utilization and fermentation end-products}

Arginine, lysine, cysteine, methionine, histidine, serine, isoleucine, Biotrypcase, yeast extract and Casamino acids were fermented but carbohydrates, organic acids and other single amino acids (alanine, proline, 

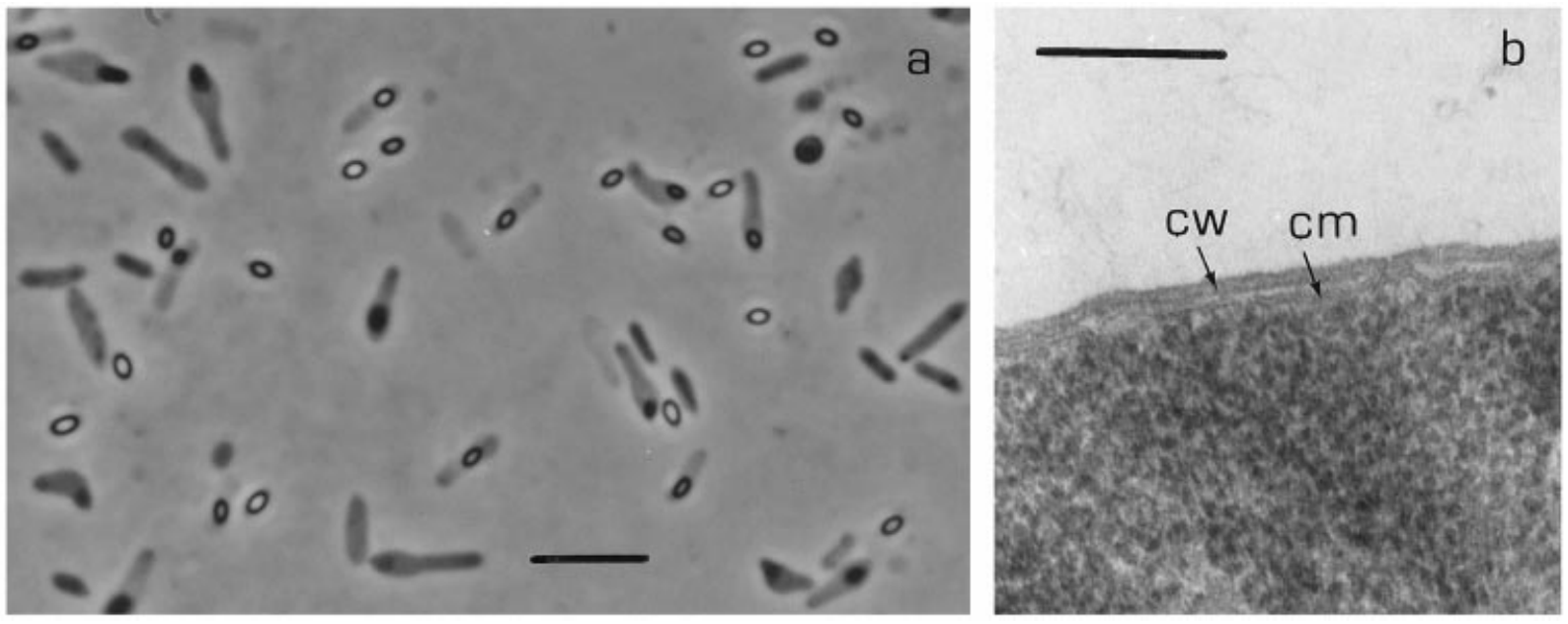

Fig. 1. (a) Phase-contrast micrograph of cells of strain $T M C 4^{\top}$ in the exponential growth phase. Bar, $10 \mu \mathrm{m}$. (b) Transmission electron micrograph of the cell wall ultrastructure of strain TMC4 ${ }^{\top}$, showing the presence of a cytoplasmic membrane $(\mathrm{cm})$ and a thick, electron-dense cell wall layer $(\mathrm{cw})$. Bar, $0 \cdot 1 \mu \mathrm{m}$.

Table 1. Fermentation of amino acids by strain TMC4 ${ }^{\top}$

Amino acids tested but not used were threonine, aspartate, asparagine, leucine, alanine, valine, glutamate, glycine, glutamine, phenylalanine, tyrosine, tryptophan and proline.

\begin{tabular}{|llc|}
\hline Amino acid & Fermentation end-products & $\begin{array}{c}\text { Maximum } \\
\mathbf{O D}_{\mathbf{5 8 0}}\end{array}$ \\
\hline Isoleucine & Methyl 2-butyrate, $\mathrm{H}_{2}, \mathrm{CO}_{2}$ & $0 \cdot 30$ \\
Histidine & Acetate, formate & $0 \cdot 32$ \\
Methionine & Propionate & $0 \cdot 40$ \\
Lysine & Acetate, butyrate & $0 \cdot 28$ \\
Arginine & Acetate, ethanol & $0 \cdot 41$ \\
Cysteine & Acetate, alanine, $\mathrm{H}_{2}, \mathrm{CO}_{2}$ & $0 \cdot 36$ \\
Serine & Acetate, $\mathrm{H}_{2}, \mathrm{CO}_{2}$ & $0 \cdot 37$ \\
Casamino acids & Acetate, butyrate, methyl & $0 \cdot 55$ \\
& 2-butyrate, $\mathrm{H}_{2}, \mathrm{CO}_{2}$ & \\
\hline
\end{tabular}

aspartate, glycine, threonine, glutamate, glutamine, leucine, aspartate, asparagine, valine, tyrosine, phenylalanine and tryptophan) were not utilized. The following amino acids were utilized from Casamino acids: serine, glycine, leucine, phenylalanine, histidine, tyrosine, lysine, arginine and isoleucine. Strain $\mathrm{TMC}^{\mathrm{T}}$ was not able to perform the Stickland reaction when cultured on the following mixtures of amino acids: histidine/aspartate, histidine/proline, valine/cysteine, valine/proline and leucine/proline. The fermentation end-products from single amino acids and Casamino acids are shown in Table 1. The fermentation endproducts from other substrates were: acetate and butyrate from crotonate; acetate, butyrate, $\mathrm{H}_{2}$ and $\mathrm{CO}_{2}$ from Biotrypcase, gelatin and peptone; and acetate, $\mathrm{H}_{2}$ and $\mathrm{CO}_{2}$ from yeast extract.
The carbon balance from cysteine fermentation was:

1 Cysteine $\rightarrow 0.65$ acetate $+0.65 \mathrm{CO}_{2}+0.42$ alanine $+\mathrm{H}_{2}$.

\section{Electron acceptor utilization}

During Casamino acid degradation, thiosulfate, but not sulfate, elemental sulfur, nitrate or fumarate, was reduced to $\mathrm{H}_{2} \mathrm{~S}$ and an increase was observed in the concentrations of the end-products acetate, propionate, butyrate, methyl 2-butyrate, $\mathrm{H}_{2}$ and $\mathrm{CO}_{2}$.

\section{DNA base composition}

The DNA $\mathrm{G}+\mathrm{C}$ content of strain $\mathrm{TMC4}^{\mathrm{T}}$ was $31 \mathrm{~mol} \%$, as determined by HPLC.

\section{Phylogeny}

Analysis of the 16S rDNA sequence showed that strain $\mathrm{TMC4}^{\mathrm{T}}$ was a member of the low-G +C-content Gram-positive bacteria and a member of cluster I (Collins et al., 1994) and, hence, was not related to most of the previously described peptide-fermenting bacteria (Baena et al., 1998, 1999a, 1999b). Cluster I is similar to the rRNA group I of Johnson \& Francis (1975), consisting of some 78 species, including Clostridium pascui and Clostridium acetireducens, and is currently the largest group of the low-G $+\mathrm{C}$-content Gram-positive clostridia. Further in-depth phylogenetic analysis indicated that $C$. pascui (sequence similarity of $96 \%$ ), rather than C. acetireducens (sequence similarity of $93 \%$ ), was the closest relative of strain $\mathrm{TMC4}^{\mathrm{T}}$. A dendrogram showing the relationship of strain $\mathrm{TMC}^{\mathrm{T}}$ to $C$. pascui and other representative members of cluster I is depicted in Fig. 2. 


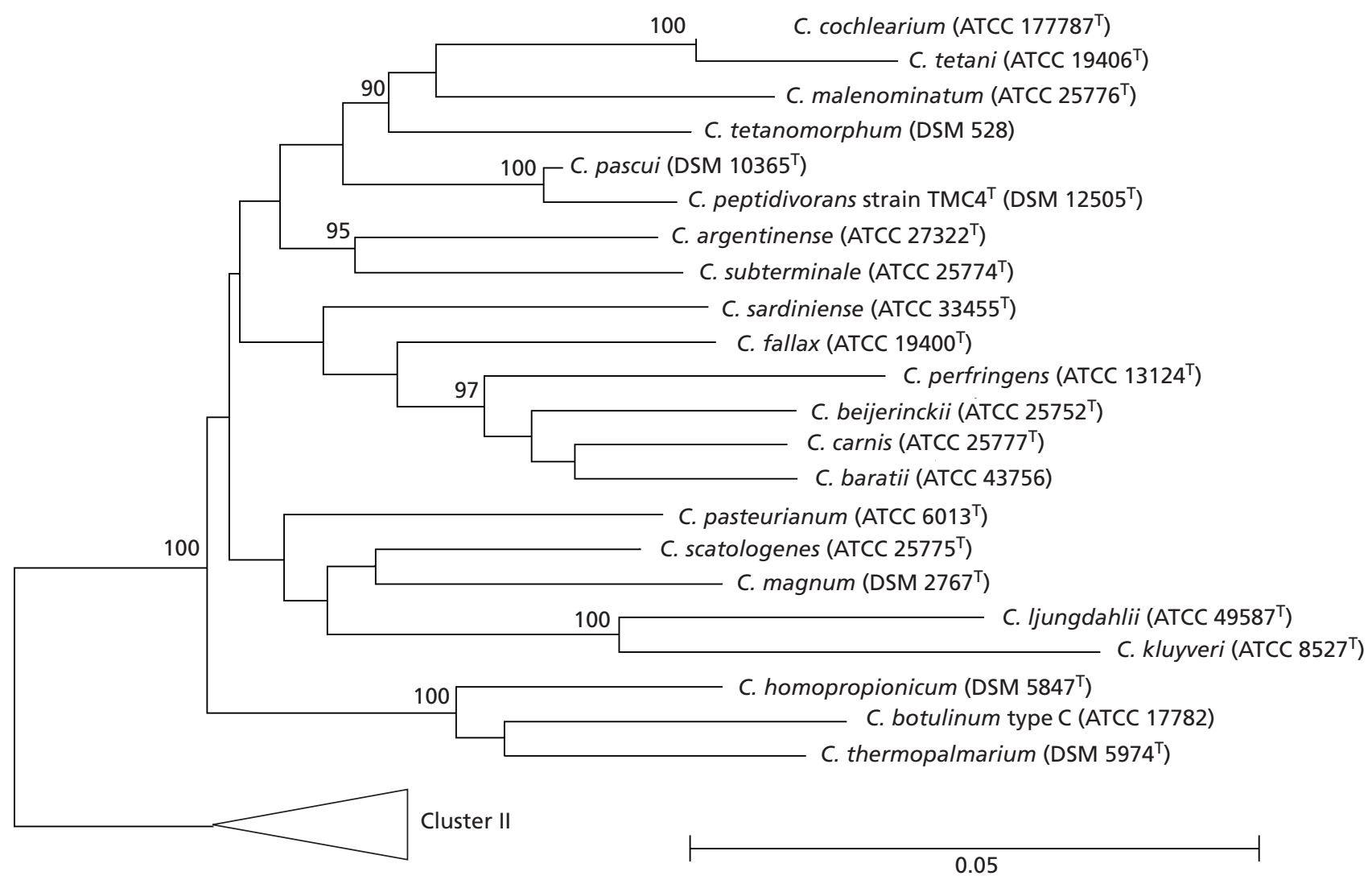

Fig. 2. Unrooted phylogenetic dendrogram based on $16 \mathrm{~S}$ rRNA sequence data indicating the position of $C$. peptidivorans strain TMC4 ${ }^{\top}$ within the radiation of representative members of the genus Clostridium (cluster I) according to Collins et al. (1994). All sequences used in the analysis were obtained from the Ribosomal Database Project, version 7 (Maidak et al., 1999). The triangle indicates representative members of cluster II (Clostridium histolyticum ATCC 19401 ${ }^{\top}$, Clostridium limosum ATCC $25620^{\top}$ and Clostridium proteolyticum ATCC $49002^{\top}$ ). Evolutionary distances (based on 1128 unambiguous nucleotides) and bootstrap analysis (100 data sets) were computed using programs that form part of the PHYLIP package (Felsenstein, 1993). Only values greater than $90 \%$ were considered significant and are therefore reported. Bar, 5 nucleotide substitutions per 100 nucleotides.

\section{DISCUSSION}

The trait of degrading proteinaceous compounds but not carbohydrates is a characteristic shared by strain $\mathrm{TMC}^{\mathrm{T}}$ with only a few members of the low-G $+\mathrm{C}$ content Gram-positive bacteria, including C. pascui, C. acetireducens, Clostridium litorale, Clostridium sticklandii, Clostridium aminophilum, Clostridium hydroxybenzoicum, Peptostreptococcus anaerobius, Acidaminobacter hydrogenoformans, Eubacterium acidaminophilum, Anaeromusa acidaminophila (formerly 'Selenomonas acidaminophila'), Dethiosulfovibrio peptidovorans, Aminobacterium colombiense and Aminomonas paucivorans. However, with the exception of C. pascui, with which it shares a sequence similarity of $96 \%$, all the other bacteria are phylogenetically distantly related. In addition, strain $\mathrm{TMC}^{\mathrm{T}}$ and $C$. pascui share the ability to ferment histidine but not carbohydrates, have similar optimum conditions for growth $\left(37^{\circ} \mathrm{C}\right.$ and $\left.\mathrm{pH} 7\right)$, form spores and are motile. However, numerous phenotypic differences also exist between the two taxa (Table 2). C. pascui stained
Gram-negative and fermented glutamate, whereas strain $\mathrm{TMC}^{\mathrm{T}}$ stained Gram-positive and did not ferment glutamate. Strain $\mathrm{TMC4}^{\mathrm{T}}$ is a proteolytic bacterium and utilized a large number of proteinaceous substrates, whereas $C$. pascui is not proteolytic and used only amino acids. The $\mathrm{G}+\mathrm{C}$ content of $\mathrm{TMC4}^{\mathrm{T}}$ is $31 \mathrm{~mol} \%$, whereas that of $C$. pascui is much lower $(27 \mathrm{~mol} \%)$. The habitats from which these two strains were isolated are also different; strain $\mathrm{TMC} 4^{\mathrm{T}}$ was isolated from an anaerobic digester whereas $C$. pascui was isolated from intestinal tracts of donkeys. A different spectrum of end-products from histidine fermentation was produced by strain $\mathrm{TMC}^{\mathrm{T}}$ (acetate and formate) when compared with $C$. pascui (acetate, butyrate, ethanol, $\mathrm{CO}_{2}$ and $\mathrm{H}_{2}$ ).

On the basis of the phenotypic, genotypic and phylogenetic evidence presented and based on the current taxonomic guidelines, we propose that strain TMC4 ${ }^{\mathrm{T}}$ should be designated as a new member of cluster I, which encompasses the true members of the genus Clostridium (Collins et al., 1994). 
Table 2. Characteristics of strain $\mathrm{TMC}^{\top}$ and C. pascui

Data for C. pascui were taken from Wilde et al. (1997).

\begin{tabular}{|c|c|c|}
\hline Characteristic & Strain $\mathbf{T M C 4}^{\mathrm{T}}$ & C. pascui \\
\hline Habitat & Olive mill wastewater digester & Intestinal tract of donkey \\
\hline Morphology & Rods, $5-10 \times 0.6-1 \cdot 2 \mu \mathrm{m}$ & Rods, $3 \cdot 2-8 \times 0 \cdot 75-1 \mu \mathrm{m}$ \\
\hline Spores & $\begin{array}{l}\text { Oval, terminal to subterminal; } \\
\text { distend the cell }\end{array}$ & $\begin{array}{l}\text { Elliptical, subterminal; } \\
\text { distend the cell }\end{array}$ \\
\hline \multicolumn{3}{|c|}{ Temperature for growth $\left({ }^{\circ} \mathrm{C}\right)$ : } \\
\hline Range & $20-42$ & $10-43$ \\
\hline Optimum & 37 & $37-40$ \\
\hline \multicolumn{3}{|l|}{$\mathrm{pH}$ for growth: } \\
\hline Range & $6-9$ & $5 \cdot 5-9$ \\
\hline Optimum & $7 \cdot 0$ & $6 \cdot 4-7 \cdot 8$ \\
\hline Substrates utilized & $\begin{array}{l}\text { Arginine, lysine, cysteine, } \\
\text { methionine, histidine, serine, } \\
\text { isoleucine, Casamino acids, } \\
\text { gelatin, yeast extract, } \\
\text { peptone, Biotrypcase }\end{array}$ & $\begin{array}{l}\text { Glutamate, histidine, ribose } \\
\text { (weakly) }\end{array}$ \\
\hline $\begin{array}{l}\text { End-products of histidine } \\
\text { fermentation }\end{array}$ & Acetate, formate & $\begin{array}{l}\text { Acetate, } n \text {-butyrate, ethanol, } \\
\mathrm{CO}_{2}, \mathrm{H}_{2}\end{array}$ \\
\hline DNA $\mathrm{G}+\mathrm{C}$ content $(\mathrm{mol} \%)$ & 31 & 27 \\
\hline
\end{tabular}

\section{Description of Clostridium peptidivorans sp. nov.}

Clostridium peptidivorans (pep.ti.di.vo'rans. N.L. n. peptidum peptide; L. v. vorare to devour; N.L. part. adj. peptidivorans peptide consuming).

Cells are motile, stain Gram-positive, are rod-shaped $(0 \cdot 6-1 \cdot 2 \times 5-10 \mu \mathrm{m})$ and form spores. Spores are terminal to subterminal and oval and distend the cell. Strictly anaerobic and grows optimally at $37^{\circ} \mathrm{C}$ over a temperature range of $20-42^{\circ} \mathrm{C}$. No growth is observed at or below $15^{\circ} \mathrm{C}$ or above $45^{\circ} \mathrm{C}$. The $\mathrm{pH}$ range for growth is between 6 and 9 with an optimum at 7.0. Grows in the presence of $\mathrm{NaCl}$ concentrations less than $4 \%$. Grows on Biotrypcase, yeast extract, Casamino acids, gelatin, peptone, arginine, lysine, cysteine, methionine, histidine, serine, isoleucine and crotonate but not on carbohydrates (glucose, fructose, xylose, sorbose, sorbitol, sucrose, melibiose, raffinose, galactose, myo-inositol, sucrose, lactose, cellobiose, mannitol, mannose, arabinose, arabitol, raffinose, cellulose or xylan ribose), organic acids (formate, acetate, propionate, $n$-butyrate, valerate, fumarate, malonate, malate, lactate, citrate or succinate) or other amino acids (alanine, proline, aspartate, glycine, threonine, glutamate, glutamine, leucine, aspartate, asparagine, valine, tyrosine, phenylalanine or tryptophan). Thiosulfate is reduced but not sulfate, elemental sulfur, nitrate or fumarate. The fermentation endproducts are: acetate and butyrate from lysine and crotonate; acetate, butyrate, $\mathrm{H}_{2}$ and $\mathrm{CO}_{2}$ from Biotrypcase, gelatin and peptone; acetate, alanine, $\mathrm{H}_{2}$ and $\mathrm{CO}_{2}$ from cysteine; acetate, $\mathrm{H}_{2}$ and $\mathrm{CO}_{2}$ from serine, cysteine and yeast extract; acetate and formate from histidine; propionate from methionine; methyl 2butyrate, $\mathrm{H}_{2}$ and $\mathrm{CO}_{2}$ from isoleucine; acetate and ethanol from arginine; and acetate, propionate, butyrate, methyl 2-butyrate, $\mathrm{H}_{2}$ and $\mathrm{CO}_{2}$ from Casamino acids. The $\mathrm{G}+\mathrm{C}$ content of DNA is $31 \mathrm{~mol} \%$, as determined by HPLC. The type strain is $\mathrm{TMC4}^{\mathrm{T}}(=$ DSM $\left.12505^{\mathrm{T}}\right)$. Isolated from an olive mill wastewater treatment digester.

\section{ACKNOWLEDGEMENTS}

Financial assistance in part to B. K. C.P. from the Australian Research Council is gratefully acknowledged.

\section{REFERENCES}

Altschul, S. F., Madden, T. L., Schäffer, A. A., Zhang, J., Zhang, Z., Miller, W. \& Lipman, D. J. (1997). Gapped BLAST and PSI-BLAST: a new generation of protein database search programs. Nucleic Acids Res 25, 3389-3402.

Andrews, K. T. \& Patel, B. K. C. (1996). Fervidobacterium gondwanense sp. nov., a new thermophilic anaerobic bacterium isolated from nonvolcanically heated geothermal waters of the Great Artesian Basin of Australia. Int J Syst Bacteriol 46, 265-269.

Baena, S., Fardeau, M.-L., Labat, M., Ollivier, B., Thomas, P., Garcia, J.-L. \& Patel, B. K. C. (1998). Aminobacterium colombiense gen. nov. sp. nov., an amino acid-degrading anaerobe isolated from anaerobic sludge. Anaerobe 4, 241-250.

Baena, S., Fardeau, M.-L., Woo, T. H. S., Ollivier, B., Labat, M. \& Patel, B. K. C. (1999a). Phylogenetic relationships of three aminoacid-utilizing anaerobes, Selenomonas acidaminovorans, 'Selenomonas acidaminophila' and Eubacterium acidaminophilum, as inferred from partial $16 \mathrm{~S}$ rDNA nucleotide sequences and proposal of Thermanaerovibrio acidaminovorans gen. nov., comb. nov. and Anaeromusa acidaminophila gen. nov., comb. nov. Int J Syst Bacteriol 49, 969-974.

Baena, S., Fardeau, M.-L., Ollivier, B., Labat, M., Thomas, P., Garcia, J.-L. \& Patel, B. K. C. (1999b). Aminomonas paucivorans 
gen. nov., sp. nov., a mesophilic, anaerobic, amino-acidutilizing bacterium. Int $J$ Syst Bacteriol 49, 975-982.

Benson, D., Lipman, D. J. \& Ostell, J. (1993). GenBank. Nucleic Acids Res 21, 2963-2965.

Collins, M. D., Lawson, P. A., Willems, A., Cordoba, J. J., Fernandez-Garayzabal, J., Garcia, P., Cai, J., Hippe, H. \& Farrow, J. A. E. (1994). The phylogeny of the genus Clostridium: proposal of five new genera and eleven new species combinations. Int $J$ Syst Bacteriol 44, 812-826.

Cord-Ruwisch, R. (1985). A quick method for the determination of dissolved and precipitated sulfides in cultures of sulfatereducing bacteria. J Microbiol Methods 4, 33-36.

Fardeau, M.-L., Ollivier, B., Patel, B. K. C., Magot, M., Thomas, P., Rimbault, A., Rocchiccioli, F. \& Garcia, J.-L. (1997). Thermotoga hypogea sp. nov., a xylanolytic, thermophilic bacterium from an oil-producing well. Int J Syst Bacteriol 47, 1013-1019.

Felsenstein, J. (1993). PHYLIP (Phylogenetic Inference Package) version 3.51c. Distributed by the author. Department of Genetics, University of Washington, Seattle, WA, USA.

Hamdi, M. (1996). Anaerobic digestion of olive mill wastewaters. Process Biochem 31, 105-110.

Hungate, R. E. (1969). A roll-tube method for the cultivation of strict anaerobes. Methods Microbiol 136, 194-198.

Johnson, J. L. \& Francis, B. S. (1975). Taxonomy of the clostridia: ribosomal ribonucleic acid homologies among the species. J Gen Microbiol 88, 229-244.

Lettinga, G. (1995). Anaerobic digestion and wastewater treatment systems. Antonie Leeuwenhoek 67, 3-28.

Macy, J. M., Snellen, J. E. \& Hungate, R. E. (1972). Use of syringe methods for anaerobiosis. Am J Clin Nutr 25, 1318-1323.

Maidak, B. L., Cole, J. R., Parker, C. T., Jr \& 11 other authors (1999). A new version of the RDP (Ribosomal Database Project). Nucleic Acids Res 27, 171-173.
Mechichi, T., Labat, M., Patel, B. K. C., Woo, T. H. S., Thomas, P. \& Garcia, J.-L. (1999). Clostridium methoxybenzovorans sp. nov., a new aromatic $o$-demethylating homoacetogen from an olive mill wastewater treatment digester. Int J Syst Bacteriol 49, 1201-1209.

Mesbah, M., Premachandran, U. \& Whitman, W. B. (1989). Precise measurement of the $\mathrm{G}+\mathrm{C}$ content of deoxyribonucleic acid by high-performance liquid chromatography. Int J Syst Bacteriol 39, 159-167.

Miller, T. L. \& Wolin, M. J. (1974). A serum bottle modification of the Hungate technique for cultivating obligate anaerobes. Appl Microbiol 27, 985-987.

Moore, S., Spackman, D. H. \& Stein, W. H. (1958). Chromatography of amino acids on sulfonated polystyrene resins: an improved system. Anal Chem 30, 1158-1190.

Redburn, A. C. \& Patel, B. K. C. (1993). Phylogenetic analysis of Desulfotomaculum thermobenzoicum using polymerase chain reaction-amplified 16S rRNA-specific DNA. FEMS Microbiol Lett 113, 81-86.

Van de Peer, Y. \& De Wachter, R. (1993). TREECON: a software package for the construction and drawing of evolutionary trees. Comput Appl Biosci 9, 177-182.

Widdel, F. \& Pfennig, N. (1981). Studies on dissimilatory sulfatereducing bacteria that decompose fatty acids. I. Isolation of new sulfate-reducing bacteria enriched with acetate from saline environments. Description of Desulfobacter postgatei gen. nov., sp. nov. Arch Microbiol 129, 395-400.

Wilde, E., Collins, M. D. \& Hippe, H. (1997). Clostridium pascui $\mathrm{sp.}$ nov., a new glutamate-fermenting sporeformer from a pasture in Pakistan. Int J Syst Bacteriol 47, 164-170.

Winker, S. \& Woese, C. R. (1991). A definition of the domain Archaea, Bacteria and Eucarya in terms of small subunit ribosomal RNA characteristics. Syst Appl Microbiol 13, 161-165. 